\title{
The Cognitive Methodology of the Porto School: Foundation and Evolution to the Present Day
}

\author{
By Eduardo Fernandes*
}

As a consequence of the international impact of the work of Álvaro Siza Vieira (Pritzker winner in 1992) and Eduardo Souto Moura (Pritzker winner in 2011), the so-called Porto School has become a global phenomenon. But the expression 'School of Porto' implies much more than the work of these two architects: it designates an identity that relates the pedagogy of a teaching institution with the ideas and architectural practice of its professors and/or former students. ${ }^{l}$ The Porto School was born as an idea of Portuguese Modern Architecture with the work of Fernando Távora, between the publication of "O Problema da Casa Portuguesa" (The Problem of the Portuguese House) in 1945 and the building of the Market in Santa Maria da Feira (1954-1959). This individual action (adapting international modern models to Portuguese physical and cultural context) became a collective trend between 1955 and 1961, the years when the Surveys on Portuguese Vernacular Architecture took place. In the early 70s, we find in Siza's work a non-visual character that reinterprets this identity and anticipates Kenneth Frampton's definition of 'critical regionalism '; in the 80s, the work of Souto Moura will emerge with a personal interpretation of this idea of School. Today, this identity subsists, as a result of the transmission mechanisms of a cognitive methodology - a way of thinking connected to a way of doing. Nonetheless, the persistence of this idea of School, nowadays, implies the respect for the heritage of its way of thinking but, paradoxically, it also needs a continuous critical exercise concerning the update of this legacy.

\section{The Script of Porto}

The identity of the Porto School is the result of the transmission mechanisms of a way of thinking connected to a way of doing. We can trace its origins back to 10th of November of 1945, when a 22-year-old student named Fernando Távora publishes a text called The Problem of the Portuguese House in a weekly journal named Áleo.

This was a very courageous text, published under the dictatorship of António Salazar and criticizing the official architectural doctrine of the fascist regime. We can find in this text the main ideas that support the identity of the Porto School: the will to learn from the past while thinking about the present

\footnotetext{
*Auxiliary Professor, School of Architecture of the University of Minho; Researcher at Landscape, Heritage and Territory Laboratory (LAB2PT, EAUM), Portugal.

${ }^{1}$ This paper summarizes the conclusions presented in Fernandes, "A Escolha do Porto" ("The Choice of Porto"), synthesizing the genesis, evolution and present awareness of the identity of the School of Porto'.

${ }^{2}$ Frampton, Modern Architecture, 313-327.
} 
and the purpose of combining the specificity of each site and cultural context with the lessons of modern architecture from the rest of the world. ${ }^{3}$

This text marks the beginning of a theoretical construct that Távora accomplishes in the next ten years, ${ }^{4}$ in a lonely and hard path, full of hesitations. But, between the mid-40s and the mid-50s, it is necessary to distinguish his theoretical and practical work: his texts present a set of ideas that (initially) he cannot materialize in his buildings.

After the evident difficulties of his early projects, the signs of the genesis of a new Portuguese Architecture begin to appear in the municipal market on Santa Maria da Feira (1954-59 - Fig. 1), a small town in the north of Portugal. This is the first work were we can recognize the full realization of the intentions expressed in his theoretical work: its modernity is expressed in the 'quality and accuracy of its relationships with life', in a 'seamless integration of all its elements'.

Figure 1. Municipal Market of Vila da Feira, Fernando Távora, 1954-59

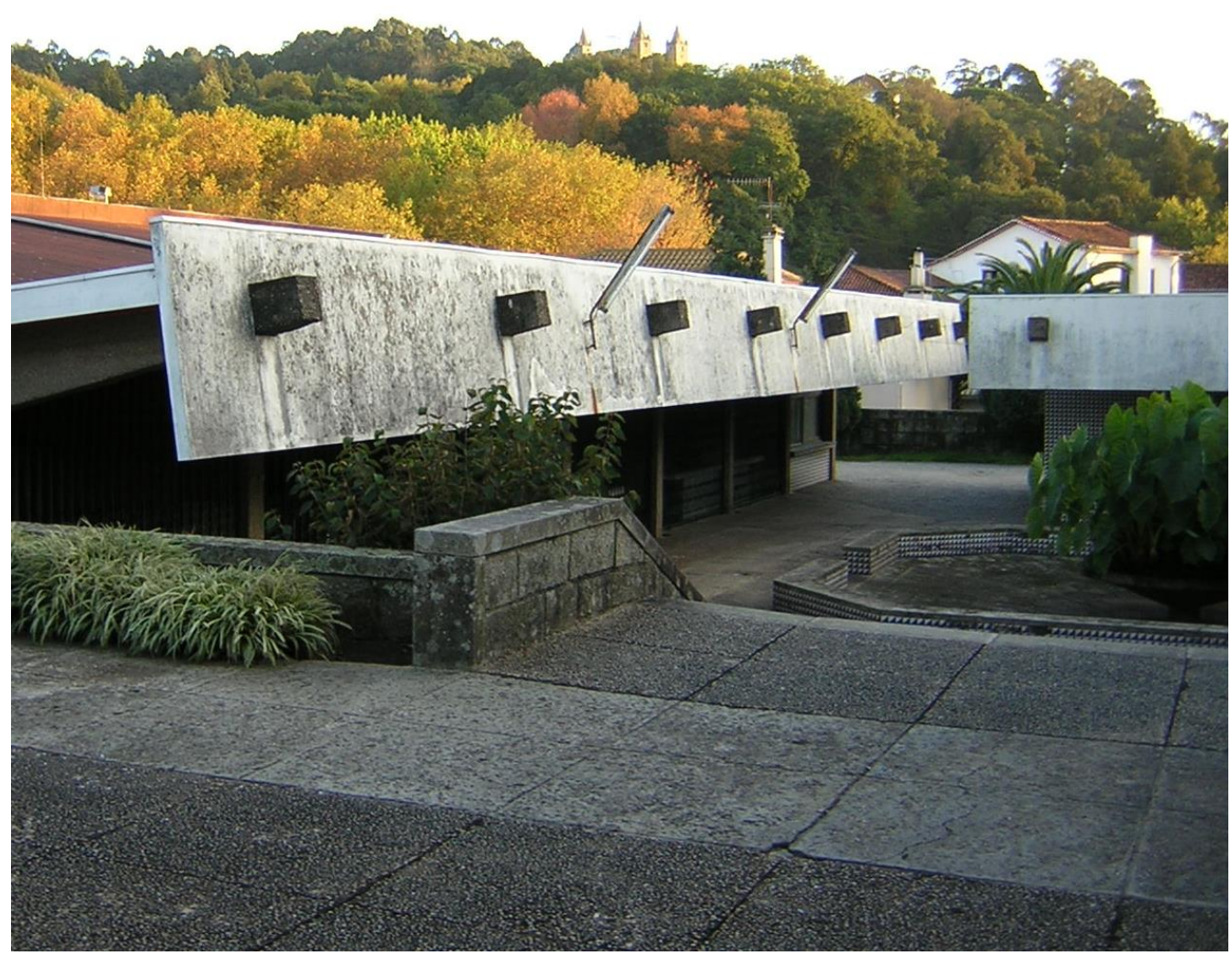

photo: Eduardo Fernandes

\footnotetext{
${ }^{3}$ Távora, "O Problema da Casa Portuguesa" ("The Problem of the Portuguese House"), 10.

${ }^{4}$ Among the antecedents that contribute to this theoretical construct, we should highlight the role of Marques da Silva and Carlos Ramos, among many others; see Fernandes, "A Escolha do Porto" ("The Choice of Porto"), 23-94.

5ávora, “Arquitectura e Urbanismo" (“Architecture and Urbanism”), 153.
} 
If the market of Santa Maria da Feira presents the seeds for the growth of the Porto School identity, they will find fertile ground between 1955 and 1961, a period marked by several events of major importance: the 1957 Reform of Architectural Teaching, the Portuguese participation on the CIAM X (1956), ${ }^{6}$ the collaboration of Álvaro Siza in Fernando Távora's office (1955-58), the first articles about the work of Siza and Távora, published by Nuno Portas in the magazine Arquitectura (1960-61) ${ }^{7}$ and the construction of paradigmatic works by Távora (that showed a new path to Portuguese Architecture), like the aforementioned market of Santa Maria da Feira, a private house in Ofír (195758), the tennis pavilion of Quinta da Conceição, in Leça da Palmeira (1956-59 - Fig. 2) and the Cedro Elementary School, in Gaia (1957-61).

Figure 2. Tennis Pavilion of Quinta da Conceição, Fernando Távora, 195659

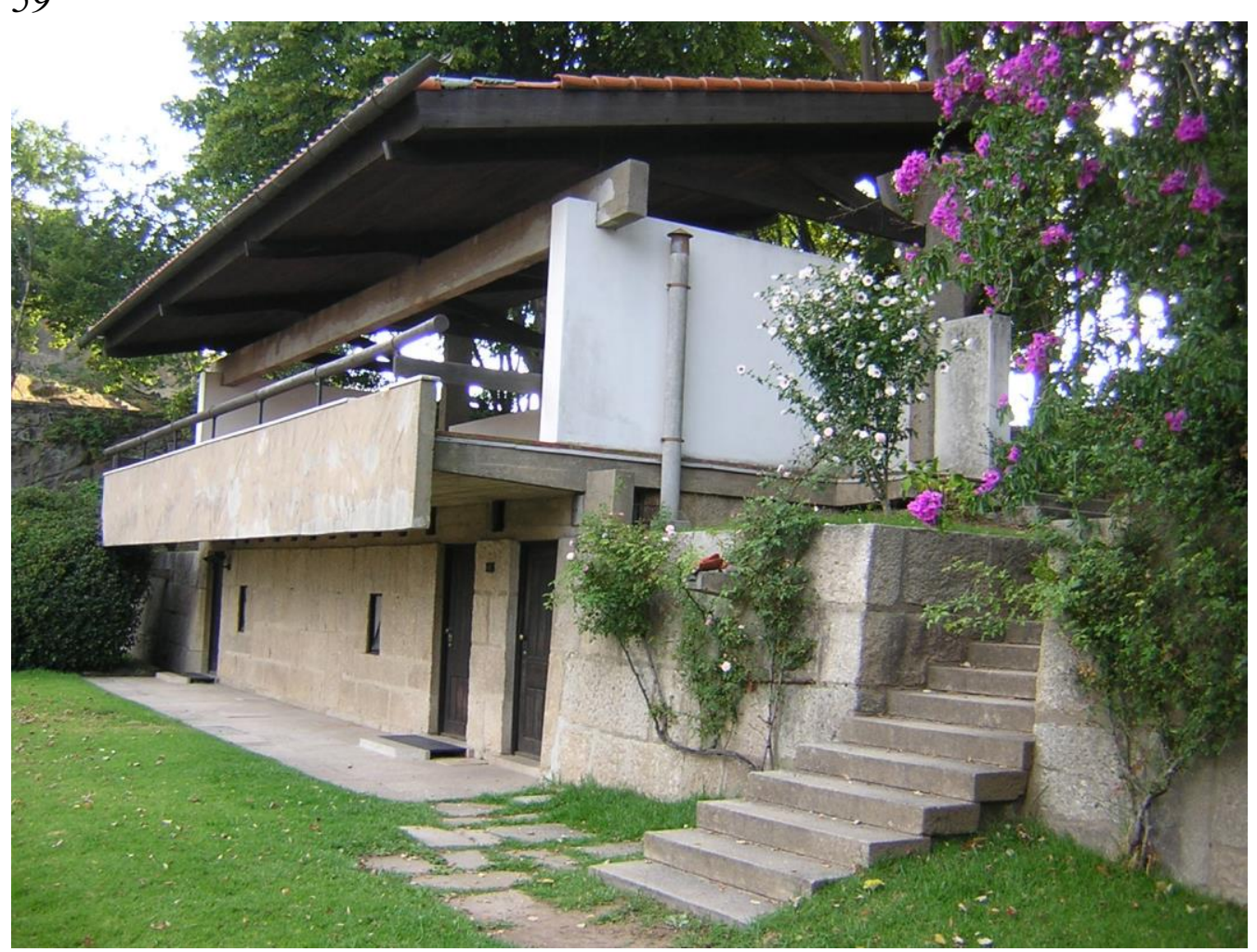

photo: Eduardo Fernandes

Most of these events are directly related with another one, that also occurred in those years and should be highlighted: the Surveys on Portuguese

\footnotetext{
${ }^{6}$ Fernando Távora was present in the last CIAM meetings (Hoddesdon, Aix-en-Provence and Dubrovnik); the presentation of the team from Porto in CIAM X reveals that the ideas expressed by Távora in 1945 were already shared by a collective identity in 1956; see Grupo CIAM Porto, "X Congresso CIAM" ("X Congress of the CIAM"), 21-28.

${ }^{7}$ Nuno Portas, "3 Obras de Siza Vieira" ("3 Works of Siza Vieira") Nuno Portas, "Fernando Távora".
} 
Vernacular Architecture (Inquérito à Arquitectura Regional Portuguesa), ${ }^{8}$ which was promoted by the Union of the Portuguese Architects (SNA) between 1955 and 1960, with the support of the government, and conducted by some of the most renowned architects from Porto and Lisbon: Fernando Távora, Lixa Filgueiras, Keil do Amaral, Nuno Teotónio Pereira, Frederico George e Artur Pires Martins.

We can frame this survey in the context of the previous studies of the same content already undertaken elsewhere, in Europe and the world. ${ }^{9}$ But in Portugal it encompassed a hidden agenda: despite the official support of the fascist regime, the intention of the promoters was to "dismantle the myths regarding Portuguese regional architecture", ${ }^{10}$ emphasizing the functionalist character of vernacular architecture.

For the professors and students of the School of Porto, this Survey was a first paradigmatic moment, which allowed the transformation of an individual though in a shared identity. From 1955 on, Távora's ideas began to be embraced collectively; ${ }^{11}$ not only by influence of his texts, but because of his work in Vila da Feira, Ofír and Leça da Palmeira, in which his colleagues could learn how to recognize the presence of 'modernity' in the Vernacular Architecture of the north of the country.

\section{The Script of Porto: Fernando Távora - Men, Land, Collaboration and Modernity}

The School of Porto was born, in the aforementioned theoretical construct of Fernando Távora, as an idea of Modern Portuguese Architecture: he defended that it should not be only Portuguese, as the official doctrine of the fascist regime intended (following the theories of Raul Lino), ${ }^{12}$ or just Modern, as supported by the younger generations of Portuguese architects in the First National Congress of Architecture (held in Lisbon, in 1948).

The defense of the need to study the Portuguese vernacular culture that Távora stated in 1945 is strengthened with the completion of the Surveys on Portuguese Vernacular Architecture, whose results present a functionalist reading of vernacular architecture. Consequently, the early work of Távora and

\footnotetext{
${ }^{8}$ Keil do Amaral, ed., Arquitectura Popular em Portugal (Surveys on Portuguese Vernacular Architecture).

${ }^{9}$ See, for example, Diez-Pastor, “Architectural Koiné”, Goodwin, Brazil Builds and Sabatino, Pride in Modesty.

${ }^{10}$ Agarez, "Vernacular, Conservative, Modernist", 35.

${ }^{11}$ Fernandes, "Signs of the 'Survey",.

${ }^{12}$ Between 1918 (date of the publication of his first book) and 1974 (year of his death), the Portuguese Architect Raul Lino published five books: A Nossa Casa - Apontamentos sobre o bom gôsto na construção das casas simples (1918), A Casa Portuguesa (1929), Casas Portuguesas - Alguns apontamentos sobre o arquitectar das casas simples (1933), Auriverde Jornada - Recordações de uma viagem ao Brasil (1937), and Os Paços Reais de Sintra (1948); he also wrote seventeen papers (published in different magazines) and more than a hundred and eighty newspaper articles (almost all in Diário de Notícias, where he collaborated assiduously since 1942). See complete bibliography in Ribeiro, Raul Lino, 195-200.
} 
Siza (in the late 50s and early 60s) is both critical of the ideas of Raul Lino and of the growing influence of the International Style in Portuguese architecture, after the abovementioned Congress of 1948.

The Surveys constituted a precious record of information about a reality that was already disappearing. But by the time of publication of the resulting book, Arquitectura Popular em Portugal, ${ }^{13}$ there was a growing regionalist trend in Portuguese architecture: we can speak of a regionalist style in which traditional techniques and building materials (in conjunction with new materials and modern construction techniques) were used with the intent of seeking formal references to vernacular architecture, even if the program and/or the context of the project should suggest other options.

This was the result of a misinterpretation of the ideas of Fernando Távora; he believed in an architecture without stylistic concerns, created with a broad functional concern (grounded not only in use but also in the identities of people and places), an architecture that responds to social-economic needs of Men and can be performed "under the conditions of the Land": the Portuguese character should be a modern response to a sum of regional conditions (socio-economic context, climate, physical environment, light, materials, etc.). So, "Men and Land" were presented as working materials and considered so important as the influence of contemporary trends, to allow the work of national architects to be done "within the Portuguese truth". ${ }^{4}$

The teaching of Architecture in the School of Fine Arts of Porto (EBAP) was based on a Vitruvian ${ }^{15}$ understanding of the role of the architect, considered to be a 'generalist expert': a technician/artist who knows how to relate to other technicians and artists. This concept implies an idea of comprehensive (but not specialized) education of the architect, in the belief that he is the single professional that, by the scope of his training, can shape the synthesis of all the different disciplines converging in architectural work.

But implicit in Távora's approach there was a new disciplinary attitude: he believed that the architect should learn to put his efforts in service of the collective, assuming architecture as a result of a 'collaboration' between all the individuals involved in the planning, design, construction and use of buildings and spaces. This concept of 'collaboration' is intended in two categories: horizontal, "manifested among men of the same time", and vertical, "which takes place between men of successive times", because the culture of the present should manifest the legacy of the past. ${ }^{16}$

Távora defined architecture emphasizing three constants in the unfolding of history. The first one is the "collaborative process" applied, as a result of the mutual relations between architect and society; the second is "modernity", understood as "the perfect integration of all the elements that can influence the

\footnotetext{
${ }^{13}$ Amaral, Arquitectura Popular em Portugal (Surveys on Portuguese Vernacular Architecture).

${ }^{14}$ Távora, "O Problema da Casa Portuguesa" ("The Problem of the Portuguese House"), 10.

${ }^{15}$ Related to the theories of the roman architect Vitruvius, author of De Architetura Libri Decem, the first known treaty of Architecture (written in the $1^{\text {st }}$. Century B. C.).

${ }^{16}$ Távora, "Da Colaboração em Arquitectura" ("Of the Collaboration in Architecture”), 5.
} 
accomplishment of the work, using all means that can lead to the better achievement of a particular purpose"; finally, the third is the quality of the space created, based on a consideration of the inherited conditions of the site, but also of the new circumstances that every architectural act creates. ${ }^{17}$ This definition also implies the plastic and artistic value of architecture ("qualitative, subjective and variable") and the essential technical aspects ("quantitative, objective and invariable"). Thus, great architecture should reflect the "exact balance of both". 18

\section{The Script of Porto: Álvaro Siza - The Architect as an Agent of Miscegenation}

The early work of Álvaro Siza Vieira remodels these fundamental concepts theorized by Fernando Távora. Siza attended Távora's classes in EBAP, and then worked in his office (for three years), being part of the collaborative processes that gave shape to ideas that, until then, had yet not surpassed a theoretical formulation. Therefore, he is the most notorious example of the transmission of this cognitive methodology, a way of thinking connected to a way of doing: the way he will reinterpret Távora's ideas in his own work will shape the future of the Porto School, redefining its identity.

Siza perceives the concept of 'modernity' in a very emphatic way, assuming and revealing the formal influences of his buildings; languages and shapes created by famous modern architects are used as work material, in a process that is close to a collage composition, implying a purpose of communication that is almost literary. In his work there is a clear conception of architecture as "figurative art", ${ }^{19}$ and this value overrides all the others, making the enjoyment of his work an experience with surprising effects, in visual, sensorial and cognitive levels.

In Siza's early work we can find a different interpretation of the concept of 'collaboration', restricted to the cooperation with the other technicians of the design team and with the artisans who work in his projects; but he defends that the architect should always have the final word (in a process of observation, evaluation of arguments and conflict mediation), making a "summary of all contributions, having scrupulously discussed and verified the correctness of each". ${ }^{20}$ His approach is based on a strategy of studying the site and the program, in an assessment that may lead to the devaluation of the characteristics of the region and/or the client's requests. Thus, 'collaboration' and 'adaptation to the environment' lead to a critical overview of the conditions of the project, expressed by the client and by all the other agents involved in the process of design, construction and use.

\footnotetext{
${ }^{17}$ Távora, “Arquitectura e Urbanismo" (“Architecture and Urbanism”), 155.

${ }^{18}$ Távora, "A posição do Artista Plástico" ("The position of the Plastic Artist"), 6.

${ }^{19}$ Portas, "3 Obras de Siza Vieira" ("3 Works of Siza Vieira"), 15.

${ }^{20}$ Siza, "A propósito do Edifício" ("About the Building”), 7.
} 
But Siza is an author; his architecture reflects the result of an artistic aspiration. His methods are a paradoxical approach to architecture design, both rational and instinctive, based in the use of sketches as a primordial tool to conceive forms and spaces. This paradox results from the methodological influence of Alvar Aalto: the ability to "include everything in the design" ('taking everything as stimulus'), the will to use "universal models", transforming them into work material that can be "manipulated", "molded in new contexts", crossed with references connoted with opposing concepts, "rooted in new realities". ${ }^{21}$ This intentional eclectic use of formal references is made possible by a vast mental archive of images; it is justified by an understanding of the role of the architect as an "agent of miscegenation", a quality that Siza also finds in Aalto, but recognizes as a feature of Portuguese historical identity (in a process of vertical collaboration).

In the early '70s, we find in Siza's work two opposing edges: a non-visual character that anticipates Kenneth Frampton's definition of 'critical regionalism ${ }^{22}$ and a complex and contradictory attitude that can be related to Venturi's thesis. ${ }^{23}$ Both these (apparently contradictory) paths can be explained as a reaction to the exhaustion of the formal influence of the Surveys on Portuguese Vernacular Architecture. His work, at this time, can be seen as a willingness to share a reflection on society, a social and urban criticism that is manifest in his collective housing projects in Caxinas, Vila do Conde (197072) and Bouça, Porto (1973 - fig. 3) and in the Beires house, in Póvoa do Varzim (1973-76). But, on the other hand, in buildings design for a rural context (like Alves Costa and Alcino Cardoso houses, 1964-71 and 1971-73, both in Moledo do Minho) we still can find the conceptual lessons of vernacular architecture, which lead to less visual qualities: authenticity, attention and character. As Gregotti noted, this was a time when Siza faced the risk of misunderstanding, exclusion and isolation, due to the subjectivity, complexity and contradiction inherent to his interpretation of the specific context of each work. ${ }^{24}$

His architecture is simultaneously poetic (harmonizing an aesthetic intention and the subliminal communication of a message) and tactile (made of sensations and details); it cannot be described in images, because it has to be experienced in the pace of a promenade (the relation between architecture and its physical context can only be perceived by an user in motion) and in a journey through memory (understanding the evolution of Siza's work and the critical use of external references in a specific site and programmatic context). His buildings are unique and inimitable, even by those who seek to follow his trail; his methods are pedagogical, but they do not indicate a clear path, because "the paths are not clear". 25

\footnotetext{
${ }^{21}$ Siza, "Alvar Aalto", 18.

${ }^{22}$ Frampton, Modern Architecture, 313-327.

${ }^{23}$ Venturi, Complexity and Contradiction.

${ }^{24}$ Gregotti, "La Passion d'Álvaro Siza", 42.

${ }^{25}$ Siza, "Oito Pontos" ("Eight Points"), 65.
} 
Figure 3. Bouça Housing, SAAL, Porto, Álvaro Siza, 1973-76, completed in 2000

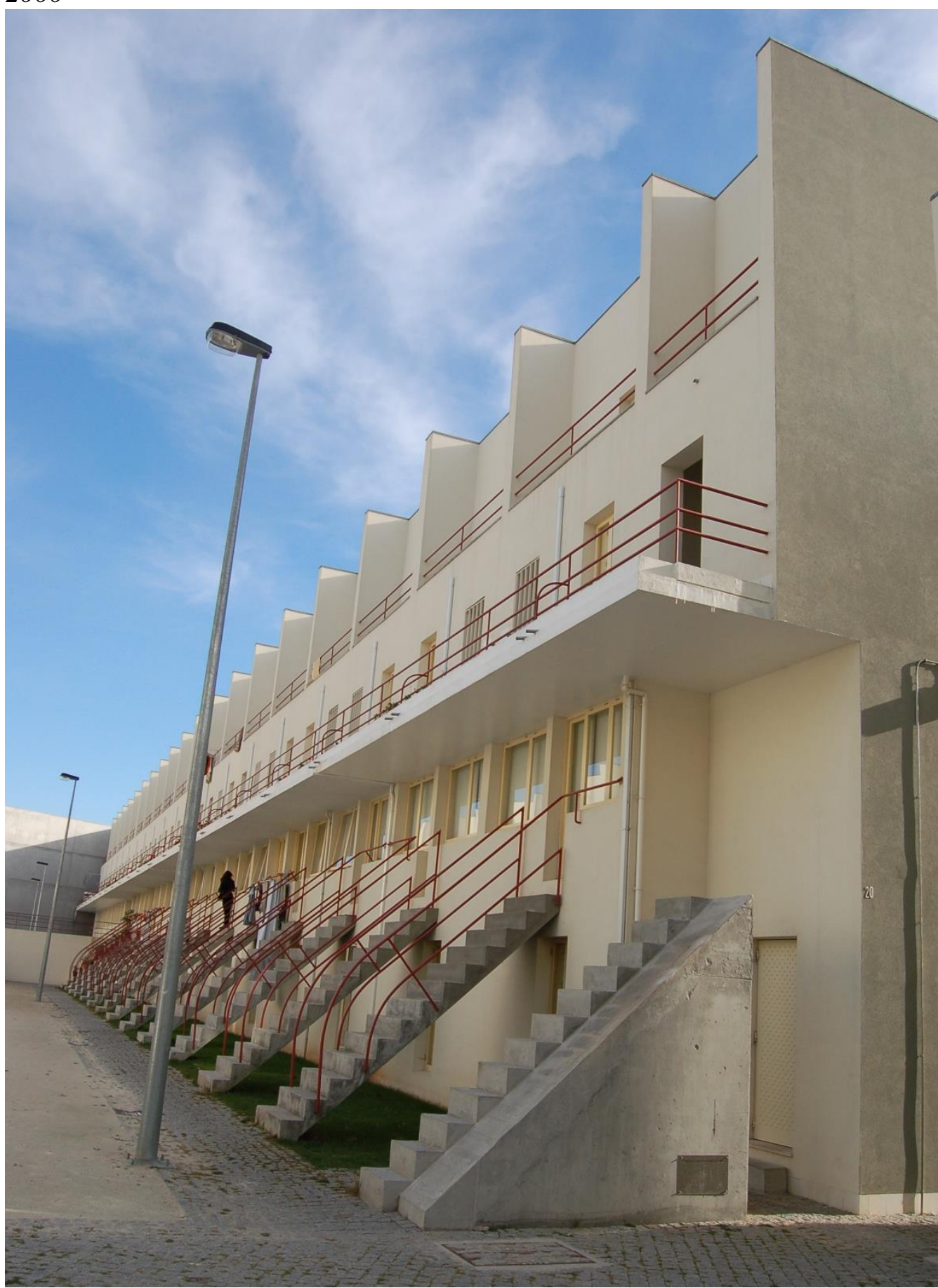

photo: Eduardo Fernandes

\section{The Script of Porto: Different Approaches of the same Identity}

Távora and Siza shared a common understanding of the role of manual drawing as a primary method of conception and synthesis in the process of 
design; in the work of both, we recognize the crossing of models and languages in a "compound that aggregates responses to multiple factors". ${ }^{26}$

However, the differences between their work were evident since 1958: in the development of Siza's projects (initiated in Távora's office) for the Tea House (1958-63 - Fig. 4) and the Swimming Pool of Quinta da Conceição (1958-65), both in Leça da Palmeira, it becomes clear the prevalence of an approach that relates the building with the site in an exercise of figurative art organized along a 'promenade architecturale' thoroughly controlled in time and space.

Figure 4. Tea House in Leça da Palmeira, Álvaro Siza, 1958-63

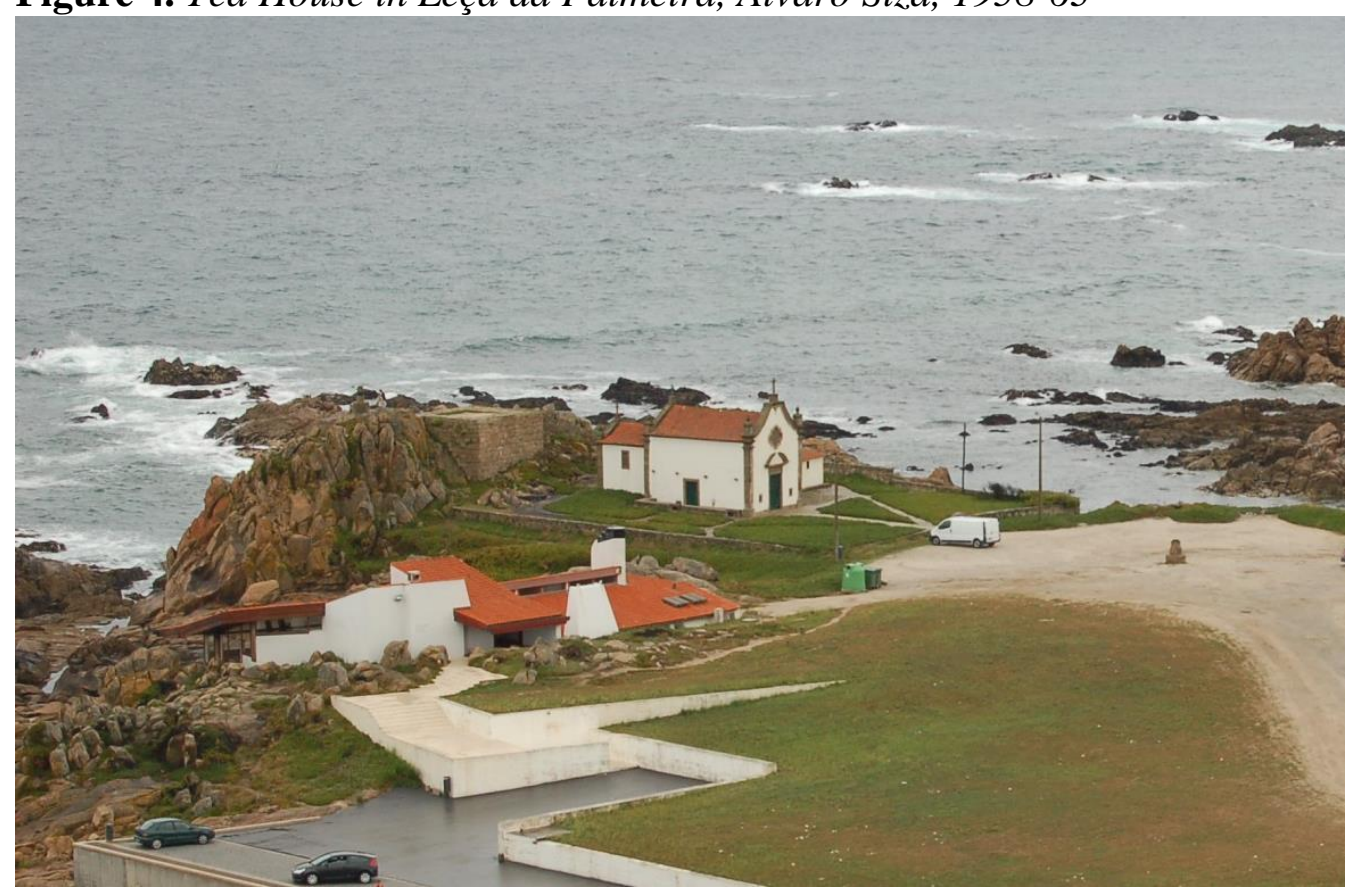

photo: Eduardo Fernandes

In the following works of Siza these differences will became clearer (Fig. 5). In the work of Távora we can always find the intent to adapt the solutions to Men and Land, in a process of 'collaboration' and 'relation with the context'. In Siza's work, the response to the binomial program/site is the starter of the process of design but the consideration of the local background may result in an introverted attitude or even in a critical position against the physical and/or social context; nevertheless, "the idea is in the site". ${ }^{27}$

\footnotetext{
${ }^{26}$ Távora, "Casa em Ofir" ("House at Ofír"), 11.

${ }^{27}$ Siza, "Notas sobre o trabalho em Évora" ("Notes on the work at Évora"), 36.
} 
Figure 5. Swimming Pool in Leça da Palmeira, Álvaro Siza, 1961-66

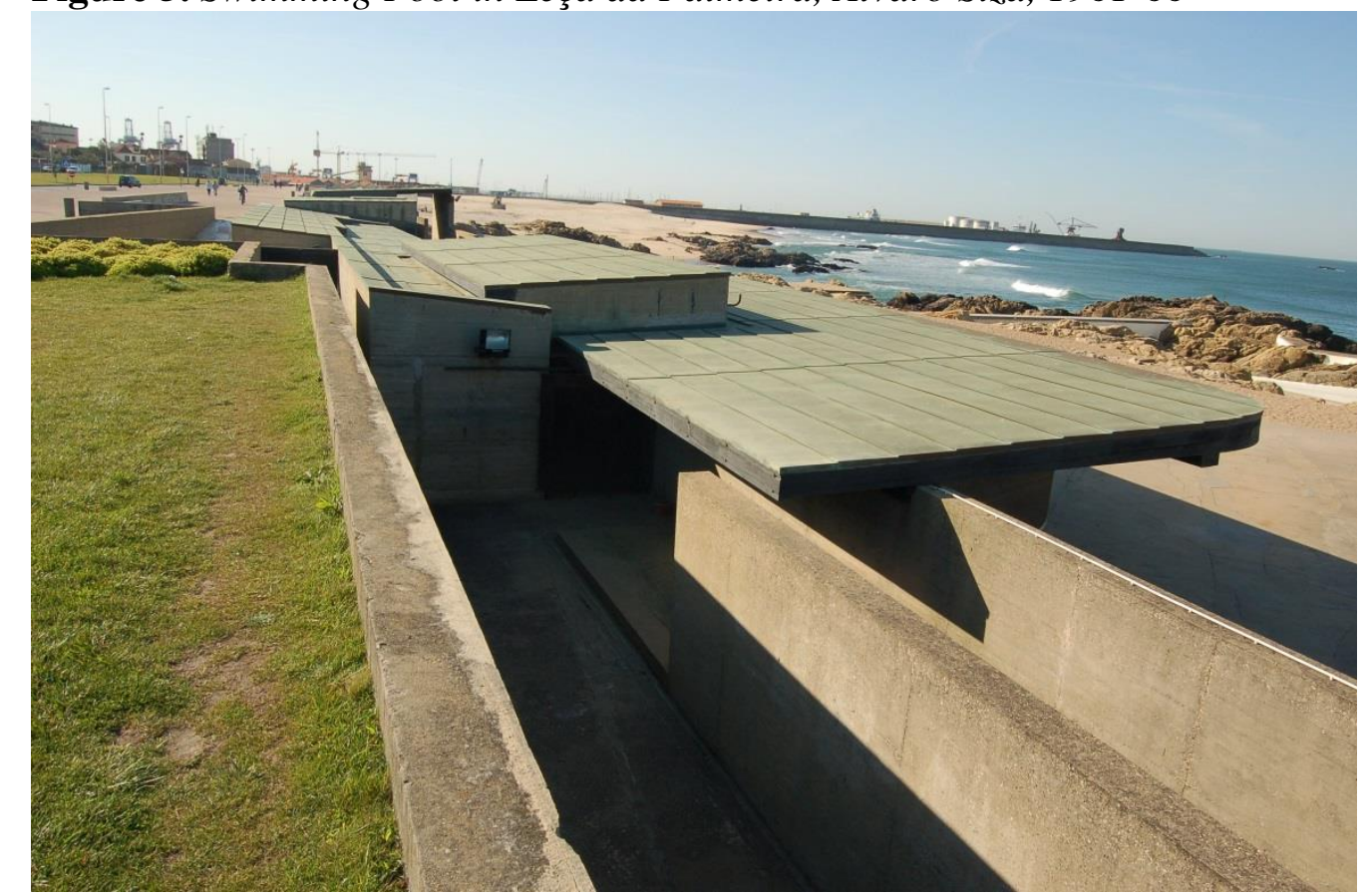

photo: Eduardo Fernandes

For Távora, the concept of 'modernity' was a timeless value, implying an adaptation to the present time in terms of effectiveness, empiricism, consistency and efficiency (a mixture of common sense and rationalism, inherited from vernacular architecture). In Siza's approach, the presence of modernity is emphasized by the eclectic use of various languages, searching an intentional confrontation of international models, in a discourse full of literary meaning.

This last evolution was misunderstood by many architects from Porto, and originated a widespread language, almost a 'style', based on a similar taste for a volumetric purity and an austere language (with references to several of the main architects and architectural movements of the first half of the twentieth century). The modern movement (in its rich diversity) is understood as a source of formal models and general principles, but rarely considered from a deeper theoretical point of view; paradoxically, the examples of vernacular architecture registered in the Surveys, no longer the source of formal influence, tend to be seen as a source of conceptual references for Portuguese identity.

\section{The Scale of Porto}

In the late '60s and early '70s, the architects of the Porto School worked in small offices, detailing meticulously small-scale buildings located in the north of Portugal. This option for a smaller scale (confronted with the dimensions of some of the greater offices that appear in Portugal, at the time, functioning like actual industries of Design) is linked to the conceptual and methodological 
influence of vernacular architecture. This is what allows Porto architects like Fernando Távora, Álvaro Siza, Alexandre Alves Costa and Sergio Fernandez (Fig.6) to search for a 'timeless way of building, ${ }^{28}$ a quality that approaches their architectures to the most genuine vernacular legacy, without waiving the awareness of its contemporaneity. In this period, scale is another feature of the identity of the School, which becomes very clear as a distinctive position of Porto in the debate on the professional status that occurred in the National Meeting of Portuguese Architects, held in Lisbon, in 1969. ${ }^{29}$

Figure 6. Holiday House in Caminha, Sergio Fernandez, 1971-73

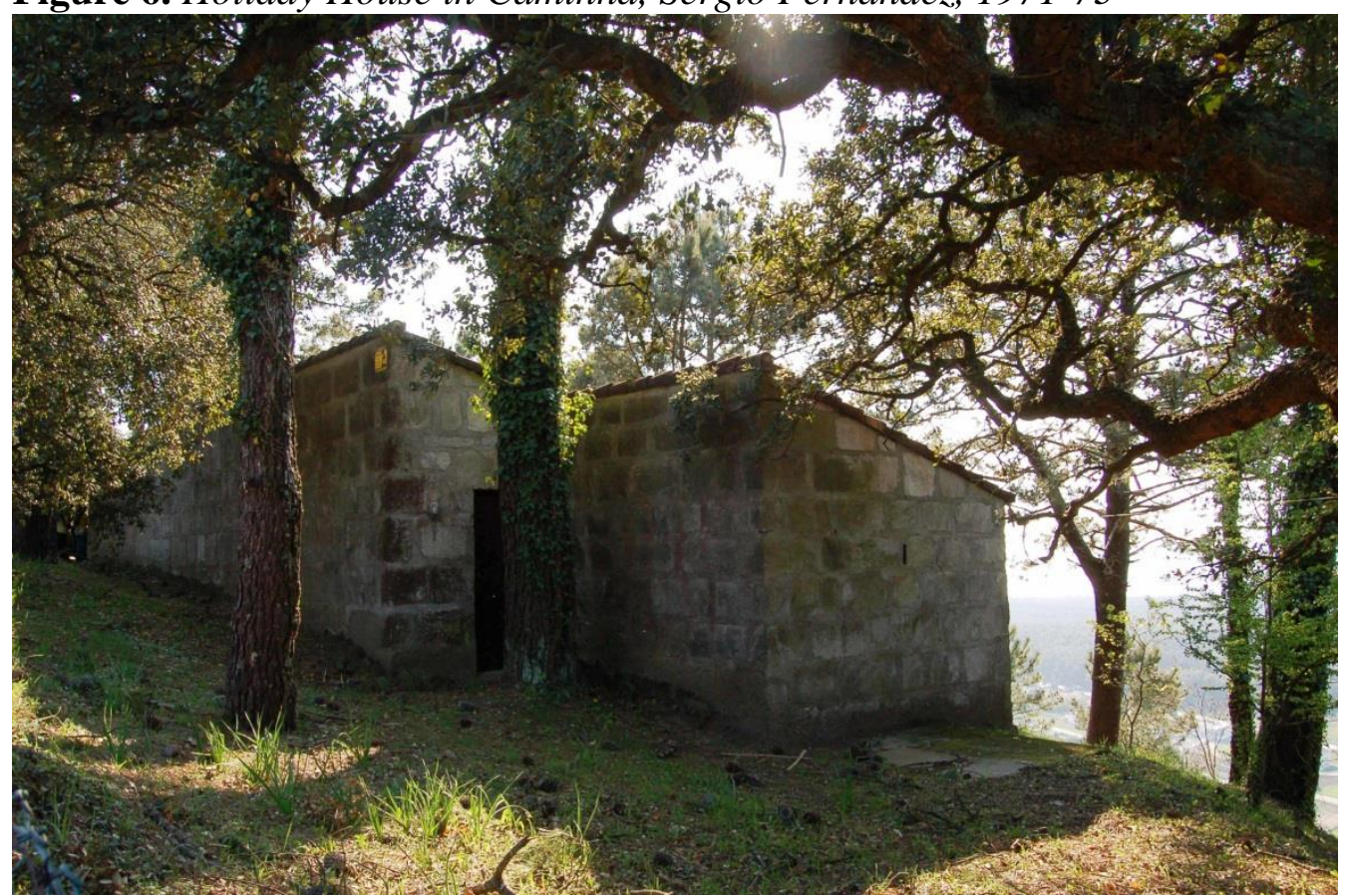

photo: Eduardo Fernandes

The revolution of April 25, in 1974, ${ }^{30}$ marks the beginning of a second stage for the Porto School. With the beginning of the SAAL Process, ${ }^{31}$ Porto architects were faced with a paradoxical situation, in defense of the principles of "the right to the city" and the "right to architecture", 32 given the urgency and scale of the needs of local populations. This was a second paradigmatic moment in the identity of the School, which implied essential issues of scale: in the relations with the urban environment and in the idea of participation of the people (in a process of 'collaboration').

\footnotetext{
${ }^{28}$ Alexander, The Timeless way of Building.

${ }^{29}$ Bandeirinha, O Processo SAAL, 89-90.

${ }^{30}$ It was this 1974 revolution that finally deposed the fascist regime that subsisted for the last 48 years in Portugal.

${ }^{31}$ The SAAL, 'Serviço Ambulatório de Apoio Local' (Ambulatory Service of Local Support), was an ambitious national social housing program created by Nuno Portas, Secretary of State of Housing and Urban Development, in June 1974, only two months after the revolution; it was promoted by the new government all over Portugal between 1974 and 1976.

${ }^{32}$ Bandeirinha, O Processo SAAL (The SAAL Process), 121.
} 
Confronted with this situation, the SAAL teams needed a different approach to enable an effective response in the short term; Porto architects would seek to create an informal (yet operational) organization, creating synergies between the various technical teams. The SAAL Process provided a laboratory field where a new interpretation of the collective identity of the School can be synthesized, where the need for rationality and economy fully justifies an attitude and language with modernist roots.

This tendency would be prolonged long after the early ending of this housing program. In the late ' 70 s and early ' 80 s this neo-modernistic approach gained momentum in opposition to the emergence of formalist languages in Europe and the United States (with great influence in Lisbon), associated with the postmodernist theories.

Then, from the mid-80s, the School of Porto has undergone another change of scale, motivated by the international impact of the work of Álvaro Siza, which triggered a growth crisis. ${ }^{33}$

Throughout the history of the School, the basis for the transmissibility of the way of thinking and of the way of doing of Porto architects was the official teaching of Architecture in Porto, first in the School of Fine Arts and, after 1984, in the Faculty of Architecture; but this transmissibility also occurred in the studios of the older architects, where common principles of method, taste and theoretical values were shared with the young disciples.

The educational system of the School of Porto is thus complemented by the practice of the studios, where the small scale allows the proximity between master and apprentice. There are similarities between the work methods in the school (where the Studio classes simulate the work of an office) and in the studio, where the same kind of approach is more realistic, because it takes place in a professional environment; so, the ateliers of the Porto architects are an unofficial complement of the official pedagogy: successive generations of students/employees, will become teachers/chief-architects, influencing new generations with their experience.

This is a system that has been proven effective over the years, but its efficiency is directly related to the size of the studios. During the 80s, there was an exponential growth of the work in the most prestigious offices of Porto; this growth occurred on the commissions (highest number of works and/or larger projects) but also on the complexity of the tasks, that tended to require rapid answers to complex programmatic questions and implied response to strict regulations.

This new professional context led to the growth of most offices, which enlarged the number of employees and became more complex in their organization. In those cases, the architects were forced to change their design process and the proximity between the masters and employees decreased. ${ }^{34}$ It was no longer possible to maintain the slow pace of the work and the methodologies based on collaboration processes (with the client, with other technicians, with the builders and handicrafts workers), allowing full control of

\footnotetext{
${ }^{33}$ Fernandes, "A Escala do Porto" ("The Scale of Porto").

${ }^{34}$ Fernandes, "A Escolha do Porto" ("The Choice of Porto"), 76.
} 
programmatic, spatial, formal and constructive aspects and dedicating full attention to the smallest of the elements of the work. ${ }^{35}$

It was this methodology that allowed the presence of the "quality without a name" 36 that we can find in the 70 s production of the Porto School and permitted an approach to the vernacular culture of the north of the country. The search for a regional identity justifies the integration of the work of Siza in the aforementioned concept of 'critical regionalism', but it becomes inappropriate when the impact of Siza's work begins to surpass his "cultural interstices". ${ }^{37}$ The former identification with a regional identity (that led to formal influences of vernacular construction, in the 50s and $60 \mathrm{~s}$, and conceptual influences of the traditional Portuguese cultures, in the 70s) is now understood as a precious memory of a reality that disappeared, a heritage that cannot be easily evoked in the light of the new socioeconomic realities.

In the $80 \mathrm{~s}$, the work of Siza evolved from 'critical regionalism' to a 'critical eclecticism', patent in the famous Bonjour Tristesse housing complex, in Berlin (1980-84), which increased the international impact of his work.

The Porto School became a global phenomenon, which changed its specificity. This process of internationalization occurred while the recognition of the national identity of Portuguese Architecture is reinforced in the discourse of Alexandre Alves Costa, which highlights the permanent values of Portuguese architecture, stating that "Portuguese architecture is characterized by the meeting of cultures" and that this "condition of miscegenation" is (paradoxically) our most distinctive feature: the innovative character of Portuguese architecture lies in this original "reinterpretation of foreign models and systems". 38

The architecture from Porto presented a timeless concept of modernism, a phenomenological approach that offered a third way to the opposition between post-modernism and neo-modernism. It presented an additional validation to the legacy of the Modern Movement, echoing images and forms created in the first half of the century. But this eclecticism coexists with the respect for the physical and cultural heritage of the sites: Portuguese Modern Architecture must be suitable to its time, but also to its place. However, it preserves a tradition of the new (a constant need to be in opposition to the dominant context) as a heritage of the heroic period.

It is important to highlight this inversion of values in the processes that traditionally characterized Portuguese specificity: the new highlighted status of the Porto School in the context of contemporary architecture embodies a national model with international impact, in contrast with the Portuguese tradition; instead of being the result of a phenomenon of acculturation

\footnotetext{
${ }^{35}$ Today, due to the economic crisis that Portugal faces, the opposite phenomenon is occurring: the scale of the studios is decreasing and most of them can't survive the shortage of architectural work.

${ }^{36}$ Alexander, The Timeless way of Building.

${ }^{37}$ Frampton, Modern Architecture, 327.

${ }^{38}$ Costa, "Notes pour une caractérisation de l'Architecture Portugaise", 15.
} 
(adapting external influences to local contexts), Portuguese architecture has now acquired universal status.

\section{The Scope of Porto}

The numerous interpretations of the theoretical identity of the School (like its architectural expression) do not present themselves as a coherent whole, with a linear sequence and a unitary language. They never did: their higher quality lies precisely in the richness of its evolutionary process, built around some (few) consensus and diverging on everything else.

But it is important to highlight that the School of Porto is the result of a theoretical construct, because this feature is not often stated in the speeches on the subject. Today, it must be seen as the result of a long journey through a winding road, guided by a set of conscious choices, in which the consciousness of the discarded path is as important as the choice of the way to go.

The ideas of the Porto School were more cohesive and coherent, as a response to Portuguese context, when this background inspired clear reactions. When, at the end of the $80 \mathrm{~s}$, the choices of Porto cease to be motivated by the response to a hostile context (the fascist regime) or a dramatic situation (the needs of the populations in the SAAL Program), the School loses coherence and internal cohesion. The interrelated critical discourses of Nuno Portas, Álvaro Siza, Manuel Mendes and Alves Costa represent a reaction to a new context, less clear and more diffuse, dominated by the appearance of a stereotypical idea of the architecture of the School, a 'Porto Style'.

This new internal criticism leads to a generalization of the idea that the term School of Porto designates an identity that no longer exists. This is also the result of the aforementioned change of scale: the School, seen as the result of the transmission mechanisms of a way of thinking connected to a way of doing, is now expanded in a complex network of mutual influences of many architects and materialized through a great number of buildings, texts and images. The list of masters is no longer limited to the inevitable names of Távora, Siza and (more recently) Souto Moura; it includes many other architects or critics with published work.

This implies that there isn't a consensus around an idea of school: there are many theoretical and practical interpretations of this identity. However, we can find new common principles in the writings of Alves Costa and in the work of Álvaro Siza (in the 80s), allowing the update of the identity of the School in a new interpretation that is justified by the history of Portuguese architecture, highlighting the 'miscegenation processes' that characterize its specificity. It explains why the languages of the Porto School can differ, according to external influences deliberately used in a process of critical eclecticism, considering the intentional relations between context, scale, function, image and meaning.

However, throughout the history of the School, two phenomena seem to coexist. The first is an uncritical reuse of formal references, reproduced from 
published images of the work of the main architects of Porto, which establishes what we can call a Porto Style: a tendency to perpetuate the repetition of forms without understanding the processes that generated them. It is the awareness of the existence of this Porto Style that justifies the various statements on the death of the Porto School that we can find, since the 90s, in the discourses on the subject.

But, on the contrary, we can also find recent examples of the transmissibility of the cognitive methods of the School (a way of thinking connected to a way of doing); they imply the consideration of the theoretic values of each external reference and its conscientious use, facing a given context and program, in an attitude that may be more or less critical of their conditions. In this case, these cognitive methods are understood and can be updated by the new generation of architects, working with new references of the present international architectural context (exponentially more complex, profuse and accessible) and with new values of national identity, allowing the appearance of languages and shapes that are (apparently) distant of what is usually considered the language of the Porto School.

\section{Conclusion}

Today, we continue to recognize in the work of the School of Porto the results of the transmission of a cognitive methodology, that relates a concern with social responsibility (perceived through the notions of 'collaboration' and 'relationship with the context') with a timeless understanding of 'modernity', the perception of architecture as figurative art, a Vitruvian understanding of the education of the architects, the practice of manual drawing as a primary method of conception and the requirement of accuracy in the processes of work and communication. We can find in the different approaches of Álvaro Siza and Souto Moura (Fig. 7) the principles of this current identity of the School of Porto, sharing the legacy of Fernando Távora as a common ground; but there is also an increasing variety of interpretations that the multiple agents of the School can do, following the same concepts.

In the globalized world where we live, the habit of miscegenation and the meeting of cultures as a condition can no longer be considered a Portuguese specificity. But the cultural heritage of the School of Porto can still present an important set of lessons on how to consciously and consequently undertake these mixing processes. The younger generations tend to assume this cultural heritage in two different ways: either seeking to preserve the core principles that characterize it or trying to find new contemporary values to update their concepts, working methods and languages. In both cases, we can find a partial extension of the theoretical identity of the School; but, in the same manner, they both partially forget this legacy. 
Figure 7. AXA Stadium, Braga, Eduardo Souto Moura, 2004

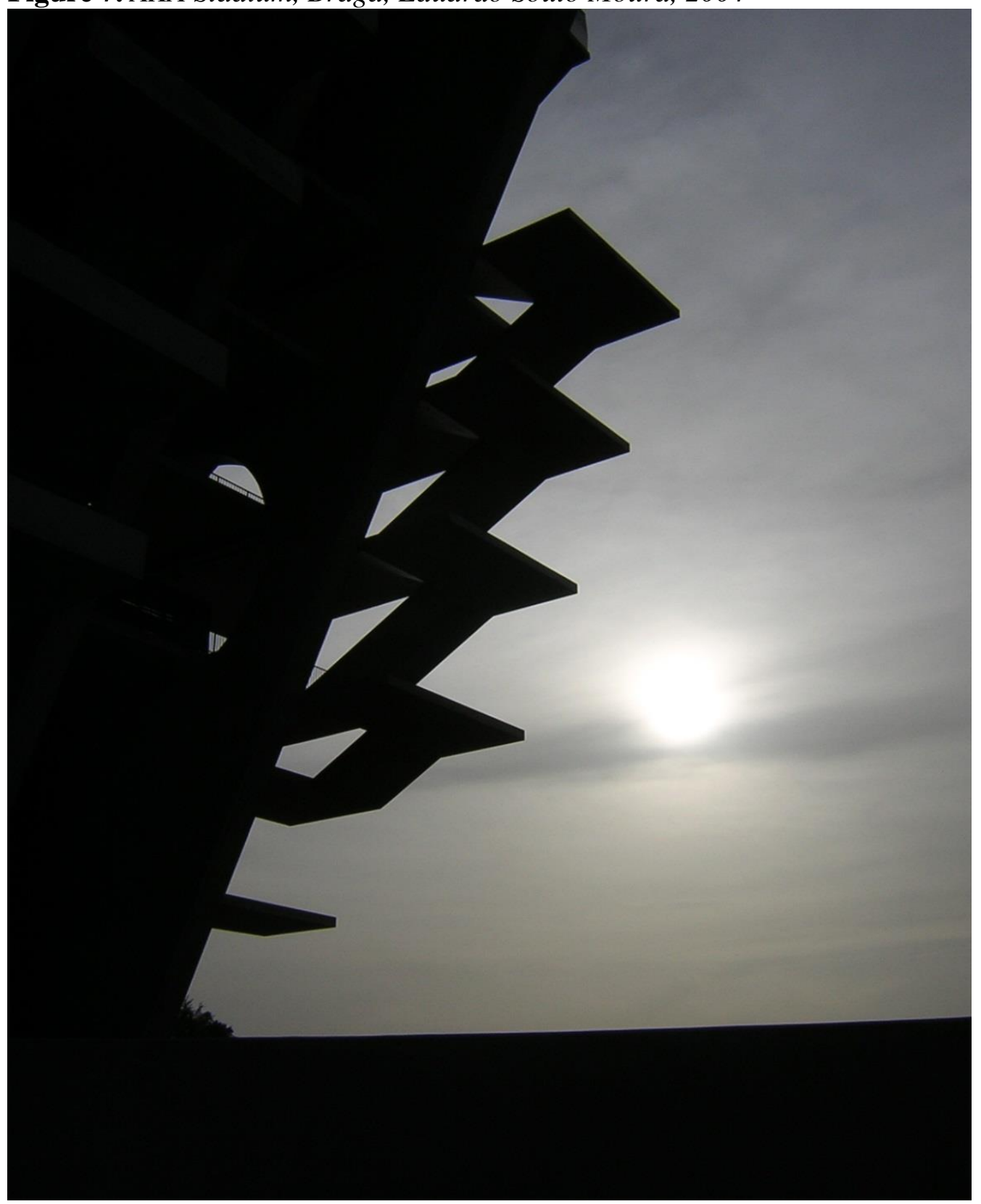

photo: Eduardo Fernandes

For the full subsistence of the cognitive methodology of the School it is necessary a third way, equidistant between the respect for inherited principles and the will to update them. We can recognize both this respect and this will in the work of some architects of the younger generations; the work of Camilo Rebelo and Tiago Pimentel (Foz Coa Museum, 2004-09 - Fig. 8), Nuno Brandão Costa (Quinta de Bouçós, in Valença do Minho, 1999-2008) or Maria Manuel Oliveira (Praça do Toural, Guimarães, 2009-12), among many others, can be presented as exemplary of this process of evolution, the same that allowed the survival of this identity from 1945 to the present day. 
Today, as always, the relationship between education, architecture and theory is crucial: to survive the trivialization of their formal models, the School of Porto needs a permanently renewed theoretical construct, adapting its pedagogy to the information society and maintaining the vitality of the methods of transmission of this way of thinking and of this way of doing.

Figure 8. Foz Coa Museum, Camilo Rebelo and Tiago Pimentel, 2004-09

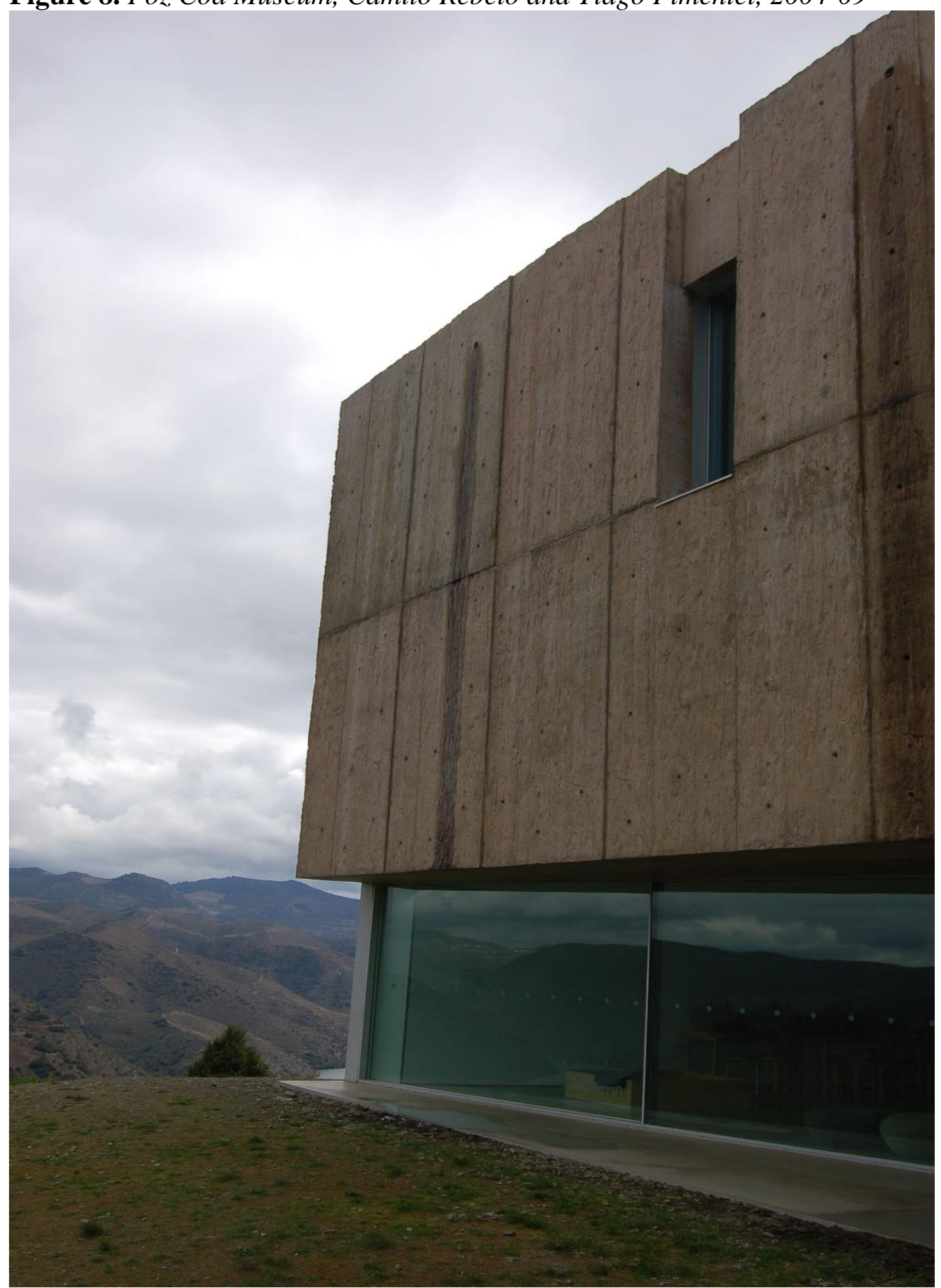

photo: Eduardo Fernandes 


\section{References}

Agarez, Ricardo. "Vernacular, Conservative, Modernist: The Uncomfortable 'Zone 6' (Algarve) of the Portuguese Folk Architecture Survey (1955-1961)." In To and Fro: Modernism and Vernacular Architecture, edited by Alexandra Cardoso, Joana Cunha Leal and Maria Helena Maia, 31-50. Porto: ESAP-CEAA, 2013.

Alexander, Christopher. The Timeless way of Building. New York: Oxford University Press, 1979.

Amaral, Keil, ed. Arquitectura Popular em Portugal (Surveys on Portuguese Vernacular Architecture). Lisboa: Sindicato Nacional dos Arquitectos Portugueses, 1961.

Bandeirinha, José António. O Processo SAAL e a Arquitectura no 25 de Abril de 1974 (The SAAL Process and the architecture on April 25, 1974). Coimbra: e|d|arq DA FCT UC, 2007.

Costa, Alexandre Alves. "Notes pour une caractérisation de l'Architecture Portugaise." In Architectures à Porto, edited by Opus Incertum, 14-41. Liége: Pierre Mardaga, 1990.

Diez-Pastor, Concepción. "Architectural Koiné: architectural culture and the vernacular in 20th century Spain." In International Conference Surveys on Vernacular Architecture. Their significance in $20^{\text {th }}$ century culture. Porto, 17-19 may 2012. Porto: ESAP-CEAA, 2012.

Fernandes, Eduardo. "A Escala do Porto" ("The Scale of Porto"). Laura, revista de cultura arquitectónica, $\mathrm{n}^{\circ} .2$ (2004): 21-27.

Fernandes, Eduardo. "A Escolha do Porto: contributos para a actualização de uma ideia de Escola" ("The Choice of Porto: contributions to update the idea of a School"). PhD thesis, School of Architecture of the University of Minho, Portugal, 2011.

Fernandes, Eduardo. "Signs of the 'Survey'. Influence in the CODA projects presented in EBAP." In International Conference Surveys on Vernacular Architecture. Their significance in 20 th century culture. Porto, 17-19 may 2012. Porto: ESAP-CEAA, 2012.

Frampton, Kenneth. Modern Architecture: a Critical History. London: Thames and Hudson, 1985.

Goodwin, Philip. Brazil Builds. New York: Museum of Modern Art, 1943.

Gregotti, Vittorio. "La Passion d'Álvaro Siza". L'Architecture D'Aujourd'Hui, n. ${ }^{o} 185$ (1972): 42.

Grupo CIAM Porto. "X Congresso CIAM" ("X Congress of the CIAM"). Arquitectura, $\mathrm{n} .^{\circ} 64$ (1959): 21-28.

Portas, Nuno. "3 Obras de Siza Vieira" (“3 Works of Siza Vieira”). Arquitectura, n. 68 (1960): 13-33.

Portas, Nuno. "Fernando Távora: 12 anos de Actividade Profissional" ("Fernando Távora: 12 years of Professional Activity"). Arquitectura, n. ${ }^{\circ} 71$ (1961): 11-34.

Ribeiro, Irene. Raul Lino - Pensador Nacionalista da Arquitectura (Raul Lino Nationalist Thinker of Architecture). Porto: FAUP, 1994.

Sabatino, Michelangelo. Pride in Modesty. Modernist Architecture and the Vernacular Tradition in Italy. Toronto: University Press, 2011.

Siza, Álvaro. "A propósito do Edifício" ("About the Building”). $66^{\circ}$ Aniversário da Cooperativa de Lordelo (1963): 7.

Siza, Álvaro. "Notas sobre o trabalho em Évora" ("Notes on the work at Évora"). Arquitectura, n. ${ }^{\circ} 132$ (1979): 36. 
Siza, Álvaro. "Alvar Aalto: Três facetas ao acaso" ("Alvar Aalto: Three random aspects"). Jornal de Letras, Artes e Ideias, n. ${ }^{\circ} 51$ (1983): 18.

Siza, Álvaro. "Oito Pontos" ("Eight Points"). In Álvaro Siza, Obras e Projectos, edited by Carlos Castanheira and Pedro de Llano, 65-66. Matosinhos: CMM / Centro Galego de Arte Contemporánea / Electa, 1995.

Távora, Fernando. "O Problema da Casa Portuguesa" ("The Problem of the Portuguese House"). ALÈO, November 10, 1945.

Távora, Fernando. "Arquitectura e Urbanismo - a lição das constantes" ("Architecture and Urbanism - the lesson of the permanencies"). Lusíada, n. 2 (1952): 151-155.

Távora, Fernando. "Da Colaboração em Arquitectura e Urbanismo" ("Of the Collaboration in Architecture and Urbanism"). Comércio do Porto, March 24, 1953.

Távora, Fernando. "A posição do Artista Plástico" ("The position of the Plastic Artist"). Jornal Comércio do Porto, August 10, 1954.

Távora, Fernando. "Casa em Ofir" ("House in Ofir"). Arquitectura, n. 59 (1957): 1013.

Venturi, Robert. Complexity and Contradiction in Architecture. New York: MOMA, 1966.

Vitruvius. De Architetura Libri Decem (1st. Cent. B. C.). Portuguese ed. (M. Justino Maciel, trans.) Lisbon: IST Press, 2006. 
